\section{Pacific Northwest}

National Laboratory

Operated by Battelle for the

U.S. Department of Energy

\title{
Biological Review of the Vegetation Removal on 218-W-6, 200 West Area, ECR \#2002-200-031
}

M. Sackschewsky

June 2003

Prepared for the U.S. Department of Energy under Contract DE-AC06-76RL01830

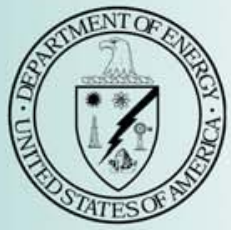




\title{
DISCLAIMER
}

This report was prepared as an account of work sponsored by an agency of the United States Government. Neither the United States Government nor any agency thereof, nor Battelle Memorial Institute, nor any of their employees, makes any warranty, express or implied, or assumes any legal liability or responsibility for the accuracy, completeness, or usefulness of any information, apparatus, product, or process disclosed, or represents that its use would not infringe privately owned rights. Reference herein to any specific commercial product, process, or service by trade name, trademark, manufacturer, or otherwise does not necessarily constitute or imply its endorsement, recommendation, or favoring by the United States Government or any agency thereof, or Battelle Memorial Institute. The views and opinions of authors expressed herein do not necessarily state or reflect those of the United States Government or any agency thereof.

\author{
PACIFIC NORTHWEST NATIONAL LABORATORY \\ operated by \\ BATTELLE \\ for the \\ UNITED STATES DEPARTMENT OF ENERGY \\ under Contract DE-AC06-76RL01830
}

Ty 
Mr. Darrin Faulk

Fluor Hanford, Inc.

P. O. Box, MSIN T4-04

Richland, WA 99352

Dear Mr.Faulk:

BIOLOGICAL REVIEW OF THE VEGETATION REMOVAL ON 218-W-6, 200 West Area, ECR \#2002-200-031.

\section{Project Description:}

- Mechanical removal of vegetation from 218-W-6, which consists of approximately 16 ha.

\section{Survey Objectives:}

- To determine the occurrence in the project area of plant and animal species protected under the Endangered Species Act (ESA), candidates for such protection, and species listed as threatened, endangered, candidate, sensitive, or monitor by the state of Washington, and species protected under the Migratory Bird Treaty Act.

- To evaluate and quantify the potential impacts of disturbance on priority habitats and protected plant and animal species identified in the survey.

\section{Survey Methods:}

- Pedestrian and ocular reconnaissance of the proposed project site were performed by M.R. Sackschewsky, J.M. Becker, and R. Durham on June 15, 2001 and by M.R. Sackschewsky onApril 22, 2002. The percent cover of dominant vegetation was visually estimated.

- Priority habitats and species of concern are documented as such in the following: Washington Department of Fish and Wildlife (1994, 1996), Washington State Department of Natural Resources (1997), and for migratory birds, U.S. Fish and Wildlife Service (1985). Lists of animal and plant species considered Endangered, Threatened, Proposed, or Candidate by the USFWS are maintained at 50 CFR 17.11 and 50 CFR 17.12. 
Mr. Darrin Faulk

2002-200-031

Page 2 of 4

\section{Survey Results:}

- 218-W-6 consists of 1) areas of mostly herbaceous vegetation and 2) areas of shrub steppe.

The shrub steppe overstory consists primarily of big sagebrush (Artemisia tridentata), spiny hopsage (Grayia spinosa), and gray rabbitbrush (Chrysothamnus nauseosus). The understory in these areas consists primarily of cheatgrass (Bromus tectorum), an alien annual weed.

The areas of mostly herbaceous vegetation are dominated by cheatgrass, crested wheatgrass (Agropyron spicatum), an introduced perennial bunchgrass used to reclaim disturbed sites, and Sandberg's bluegrass (Poa sandbergii), a native perennial bunchgrass.

- The Western meadowlark (Sturnella neglecta) was observed in the shrub steppe areas of the project and the killdeer (Charadrius vociferous) was observed in areas dominated by herbaceous vegetation. Both are ground-nesting species and likely nest within the respective habitats in which they were observed. The lark sparrow (Chondestes grammacus) was observed in shrub steppe areas and the loggerhead shrike (Lanius ludovicianus) was observed in areas dominated by herbaceous vegetation. However, both are shrub-nesting species and thus may nest in the shrub steppe areas of 218-W-6.

Other avian species were also observed in the project area, e.g., Say's phoebe (Sayornis saya) and barn swallow (Hirundo rustica). However, these species nest neither in shrubs nor on the ground. Thus, these would most likely not be found nesting in the project area.

\section{Considerations and Recommendations:}

- No plant or animal species protected under the ESA, candidates for such protection, or species listed by the Washington state government as threatened or endangered were observed in the vicinity of the proposed site.

- The migratory bird species listed above were observed in the project area. Of these, the Western meadowlark, killdeer, lark sparrow, and loggerhead shrike could nest in the project area, based on the known nesting preferences cited above.

- The nests, eggs, and young of migratory birds are protected under the Migratory Bird Treay Act (MTBA). 
Mr. Darrin Faulk

2002-200-031

Page 3 of 4

- The duration of the nesting season generally falls between March 1 and July 31.

- We recommend that vegetation removal on 218-W-6 occur outside the nesting season (i.e., August 1 through February 28), in order to avoid potential adverse impacts to nesting individuals and/or their young and to comply with the MBTA.

- This Ecological Compliance Review is valid until 15 April 2003.

Sincerely,

Michael R. Sackschewsky

Project Manager

Ecological Compliance Assessment Project

MRS:jmb 
Mr. Darrin Faulk

2002-200-031

Page 4 of 4

\section{REFERENCES}

U. S. Fish and Wildlife Service. 1985. Revised List of Migratory Birds; Final Rule. 50 FR 13708 (April 5, 1985).

Washington Department of Fish and Wildlife. 1994. Species of Special Concern in Washington. (April 1994).

Washington Department of Fish and Wildlife. 1996. Priority Habitats and Species List. (January 1996).

Washington Department of Natural Resources. 1997. Endangered, Threatened \& Sensitive Vascular Plants of Washington (August 1997). 